\title{
COMPLAINT ANALYSIS USING 8D METHOD WITHIN THE COMPANIES IN THE FIELD OF AUTOMOTIVE ${ }^{1}$ V. Alexa, ${ }^{2}$ I. Kiss \\ ${ }^{1-2}$ University Politehnica Timişoara, Faculty of Engineering Hunedoara, Department of Engineering and Management, 5, Revolutiei, 331128, Hunedoara, Romania e-mail: vasile.alexa@fih.upt.ro,imre.kiss@fih.upt.ro
}

\begin{abstract}
The eight disciplines (8D - Eight Disciplines of Problem Solving) model is a problem solving approach typically employed by quality engineers or other professionals and commonly used by the automotive industry. It is a meticulous process used to solve complex problems and its purpose is to identify, correct, and eliminate recurring problems, and it is useful in product and process improvement. The $8 \mathrm{D}$ is a method of analysis that after the detection of an irregularity, identifies and seeks the methods of solving and preventing nonconformity. It is a highly disciplined and effective scientific approach for resolving recurring problems and provides excellent guidelines to identify the root cause of the problem, implement containment actions, develop and then implement corrective actions and preventive actions that make the problem go away permanently. Therefore, the Eight Disciplines of Problem Solving (8D) is a problem-solving tool used usually in response to the removal parameters or known product specifications set by customers and incorporates all the important aspects of problem solving: problem description, root cause analysis, correcting the problem and preventing the problem. The approach establishes a permanent corrective action based on statistical analysis of the problem and focuses on the origin of the problem by determining its root causes. Although it originally comprised eight stages, or disciplines, it was later augmented by an initial planning stage. The $8 \mathrm{D}$ method application will result in improved products and processes is structured into eight disciplines, focusing on the synergy of the team. This is a popular method for problem solving because it is reasonably easy to teach and effective.
\end{abstract}

Keywords: nonconforming, compliance, eight disciplines, quality

\section{INTRODUCTION}

The 8 Discipline is a method akin to FMEA (Failure Mode and Effect Analysis). One of the essential differences between the two methods is that by $8 \mathrm{D}$ action is taken to remedy faults and eliminate their causes after non-compliance occurs when, through the FMEA try to anticipate their cause's defects. The $8 \mathrm{D}$ method is only recommended in cases with unknown cause of the occurrence of non-compliance. Method 8 Discipline comprises the following steps, presented in Fig.1.

\section{D1. Introduction and setting up the team}

D2. Content description of the problem

D3. Measures/actions immediate to keep the control of the problem

D4. Cause and effect analysis

D5. Defining corrective measures and highlighting their effectiveness

D6. Implement corrective actions and prove their effectiveness

D7.Defining measures / preventive actions

D8. Final discussion and congratulations

Figure 1. Method 8 Discipline steps 


\section{CASE STUDY ON APPLYING THE 8D METHOD}

Next, presents a new diagram comprising the steps of applying the 8D Method, but this time the focus is on the period of time in which each stage (discipline: D1-D8; D0 signifies a stage where it is established that there was a problem; $\mathrm{D} 0$ is the pre-initiation process $8 \mathrm{D}$ ).

Table 1. Step D0: Introduction

\begin{tabular}{|c|c|}
\hline Customer number & 21270357 \\
\hline Customer location & XXXX \\
\hline Product Number & 0234123413 \\
\hline Number of complaints & 196304349975 \\
\hline Quantity & $60 /$ box \\
\hline Complaint date & 07.07 .2015 \\
\hline Date for delivery & 27.06 .2015 \\
\hline
\end{tabular}

\subsection{Step D1: Introduction and setting up the team}

In the first stage selection takes place team members. Nomination team members with the skills and knowledge described necessary content problem. It is generally responsible product in which the problem occurred.

The team will hold a maximum of 5 people with selecting a leader. The team should include the responsible department.

\subsection{Step D2: Content description of the problem}

Will perform collection of information, data, facts, figures. Description of the problem (fault/deviation) as accurately as possible, providing quantitative information (facts, figures, data, effect on Clients etc.). As actions to be taken in $\mathrm{D} 2$ are:

$\equiv$ collecting evidence (good / defective);

$\equiv$ gather and evaluate objective data;

$\equiv$ viewing the facts (photos, drawings, sketches)

Precise description of the fundamental problem based only on facts!

The customer received a delivery with delivery note 114643176 , dated 06/27/2015 regarding this delivery for delivering customer complained, the fact that the packaging finished goods did not comply with its specifications.
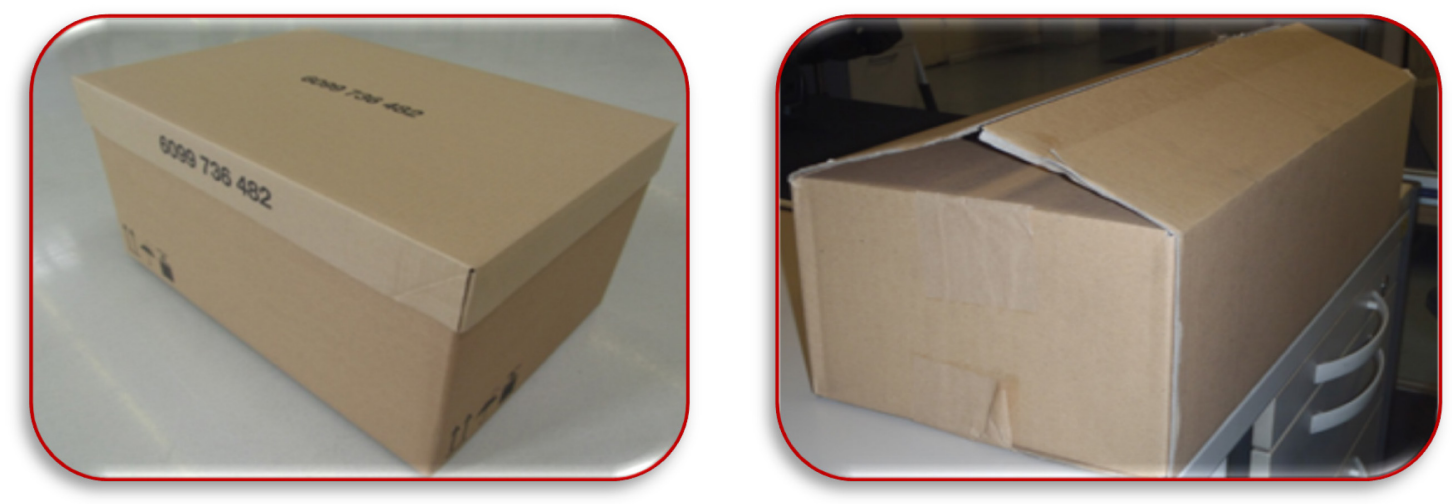

Figure 2. Pack the faulty product 


\subsection{Step D3: Measures/actions immediate to keep the control of the problem}

The purpose of this step is controlling the product so that non-compliance does not arise to the customer. The measures serve only as immediate protective actions and often have no connection with the causes of the problem. Develop a program/plan for implementing immediate actions to isolate the problem. Immediate action to be replaced by corrective measures defined in steps D5 and respectively in D6.

$\equiv$ causes of the problem, that immediate action was to inform all operators in the supply area to realize the mistake that could be avoided with ease;

$\equiv$ create a packaging instructions on the specific requirements of each client;

$\equiv$ creating a Poka Yoke system to prevent them from wrong packing.

This can be achieved by the computerized system used (SAP) where every customer looks for materials that must be used in packing).

\subsection{Step D4: Cause and effect analysis}

Determining the "root cause" technical and managerial: TRC (Technical Root Cause) and RCM (Root Cause Management). Apply technical questions: "5 Why? ".

To determine and verify and verify functional causal relationship technical root cause (TRC).

Identify root cause management (CRM) causing technical root cause. Provides an assessment of risks, including severity, likelihood and extent of this defect/noncompliance.

Table 2. Technique of the 5 questions: WHY?

\begin{tabular}{|c|c|c|}
\hline \multicolumn{2}{|c|}{ Problem 1} & $\begin{array}{l}\text { The packaging used to wrap the finished product does not meet customer requirements. } \\
\text { TECHNICAL ROOT CAUSE }\end{array}$ \\
\hline 1 & WHY? & $\begin{array}{l}\text { The operator responsible for wrapping, packing not complied with the instruction provided. } \\
\text { MANAGEMENT ROOT CAUSE }\end{array}$ \\
\hline 2 & WHY? & $\begin{array}{l}\text { Operator who carried out the packing was taken to another workstation, which is why he did } \\
\text { not know and was not clearly informed that the instructions casing. }\end{array}$ \\
\hline 3 & WHY? & $\begin{array}{c}\text { Due to the reduced staff work area was needed by other operators for packaging finished } \\
\text { products and so deliver on time. }\end{array}$ \\
\hline \multicolumn{2}{|c|}{ Problem 2} & Packaging did not comply with specifications. \\
\hline 4 & WHY? & $\begin{array}{l}\text { There is a double check after packing the finished product. } \\
\text { TECHNICAL ROOT CAUSE / MANAGEMENT ROOT CAUSE }\end{array}$ \\
\hline 5 & WHY? & This failure was not taken into account. \\
\hline
\end{tabular}

Risk assessment:

$\equiv$ there is no risk that the final product delivered to affected or destroyed.

$\equiv$ this issue relates only to the packaging, not the product.

\subsection{Step D5: Defining corrective measures and highlighting their effectiveness}

Identification and assessment of corrective measures "optimal" addressing the root causes of technical and managerial identified.

Define potential remedial measures to eliminate the root causes (occurrence and detection).

\subsection{Step D6: Implement corrective actions and prove their effectiveness}

Implementation of the plan / program implementation of corrective measures aimed at removing technical and managerial causes identified.

After validating the effectiveness of their implementation and ensure that there are no side effects/negative correlated, i.e. monitoring process both internally and to the customer. 


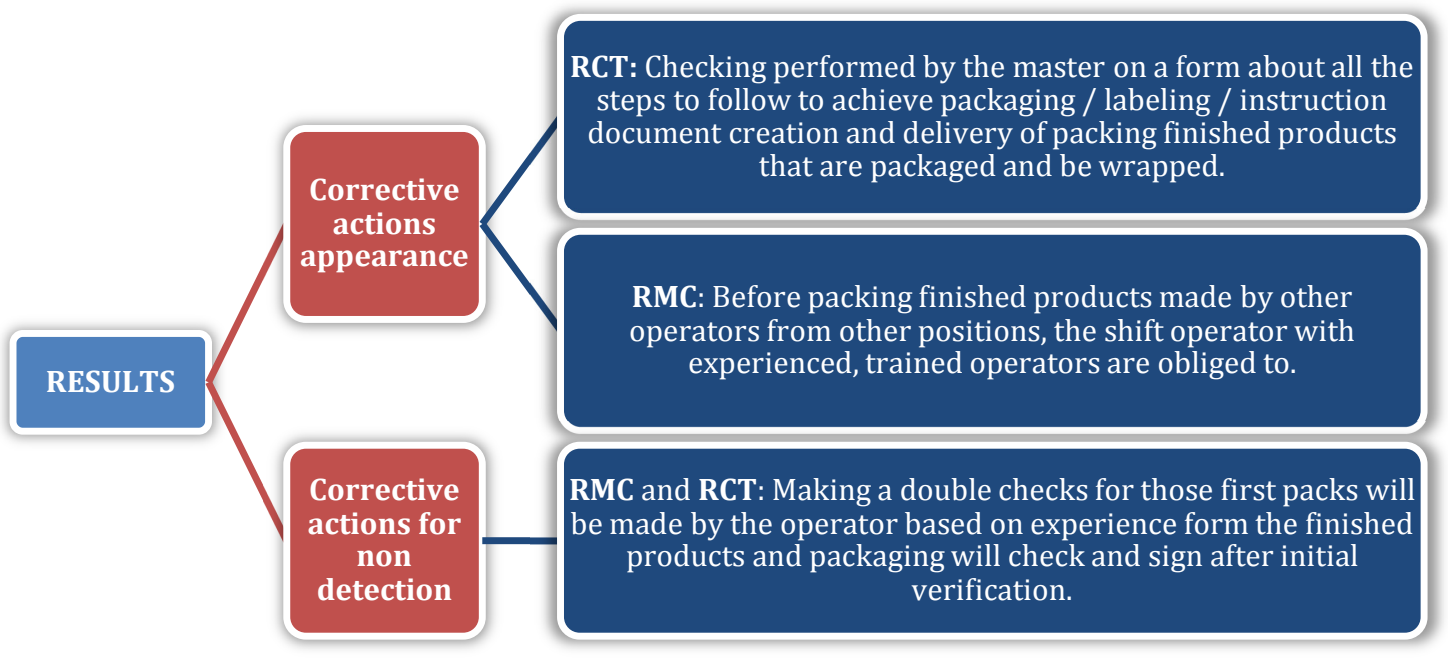

Figure 3. The corrective actions

\subsection{Step D7: Defining measures / preventive actions}

Identifying preventive actions to avoid problems / defects in the similar processes of production / logistics. Will ensure that there will be no risk of recurrence by updating the monitoring system of all processes and work instructions affected. (Eg FMEA, control plan, drawing, work instructions, training).
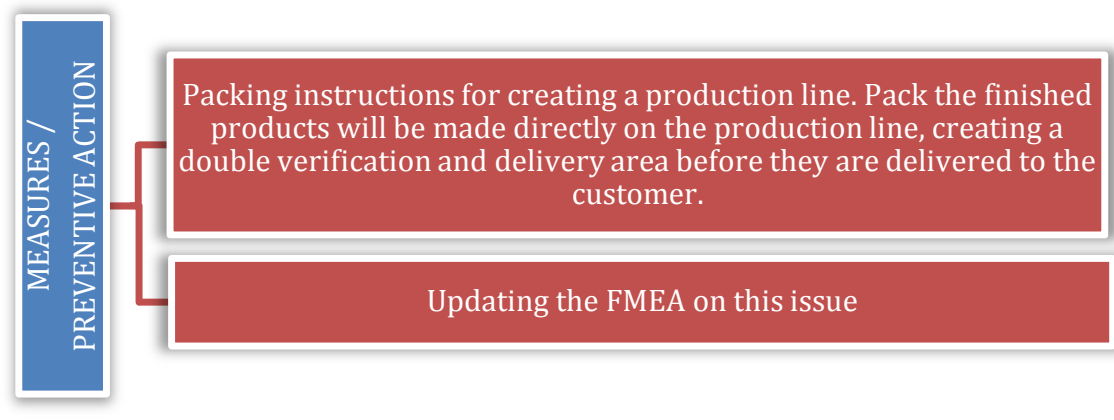

Figure 4. Measures / preventive actions

\subsection{Step D8: Final discussion and congratulations}

The $8 \mathrm{D}$ team pursuit final meeting. It will conduct a critical evaluation of the actions implemented and 8D report. 8D report will close. 8D recognition and greeting their team's efforts.

The 8D report will archive with additional documents. 07/30/2015 final session.

The causes have been identified, measures and action were defined and efficiency actions will be monitored for six weeks.

\section{CONCLUSIONS}

The purpose of instruction on creating packaging for finished products on the production line will lead to a decrease in time packing and especially timely delivery of products to the end customer. 
Instruction working on packing the finished products is performed by the logistics department, and if deviations occur (change packaging of certain products) production will get the support of logistics.

This improvement was monitored for 12 weeks to see if it is effective measure.

Mini flow on the finished product packaging (Fig. 5) connected directly on the production line.

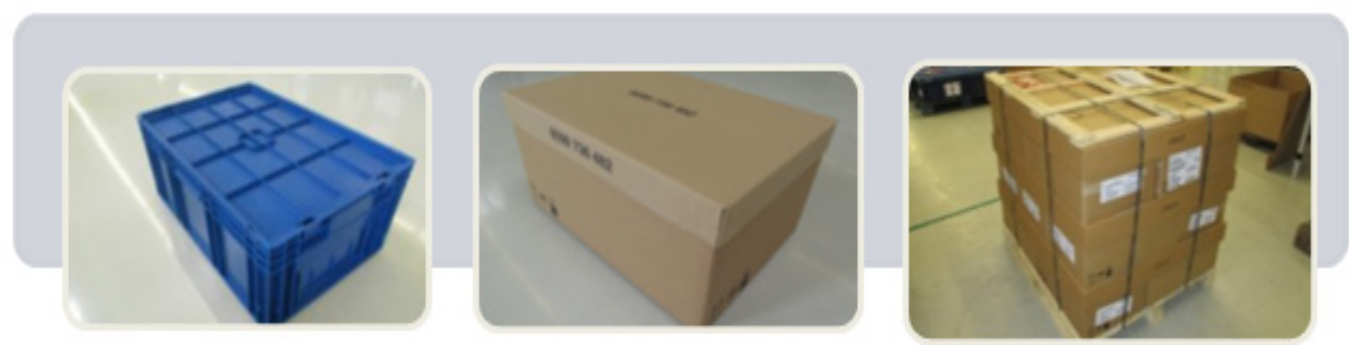

Figure 5. Mini packaging process flow

In the table below are data on the monitoring of 14 weeks.

Table 3. Monitoring the packaging process

\begin{tabular}{|c|c|c|c|c|c|c|c|}
\hline Date & $03-14.08$ & $17-28.08$ & $31.08-11.09$ & $14-25.09$ & $28.09-09.10$ & $12-23.10$ & $26.10-06.11$ \\
\hline $\begin{array}{c}\text { Total } \\
\text { package }\end{array}$ & 1.454 .540 & 359.661 & 150.592 & 1.724 .303 & 761.814 & 730.920 & 904.340 \\
\hline $\begin{array}{c}\text { Customer } \\
\text { packaging }\end{array}$ & 445.289 & 167.678 & 71.234 & 883.601 & 480.288 & 468.108 & 599.890 \\
\hline Percentage & $30.61 \%$ & $46.62 \%$ & $47.30 \%$ & $51.24 \%$ & $63.05 \%$ & $64.04 \%$ & $66.33 \%$ \\
\hline
\end{tabular}

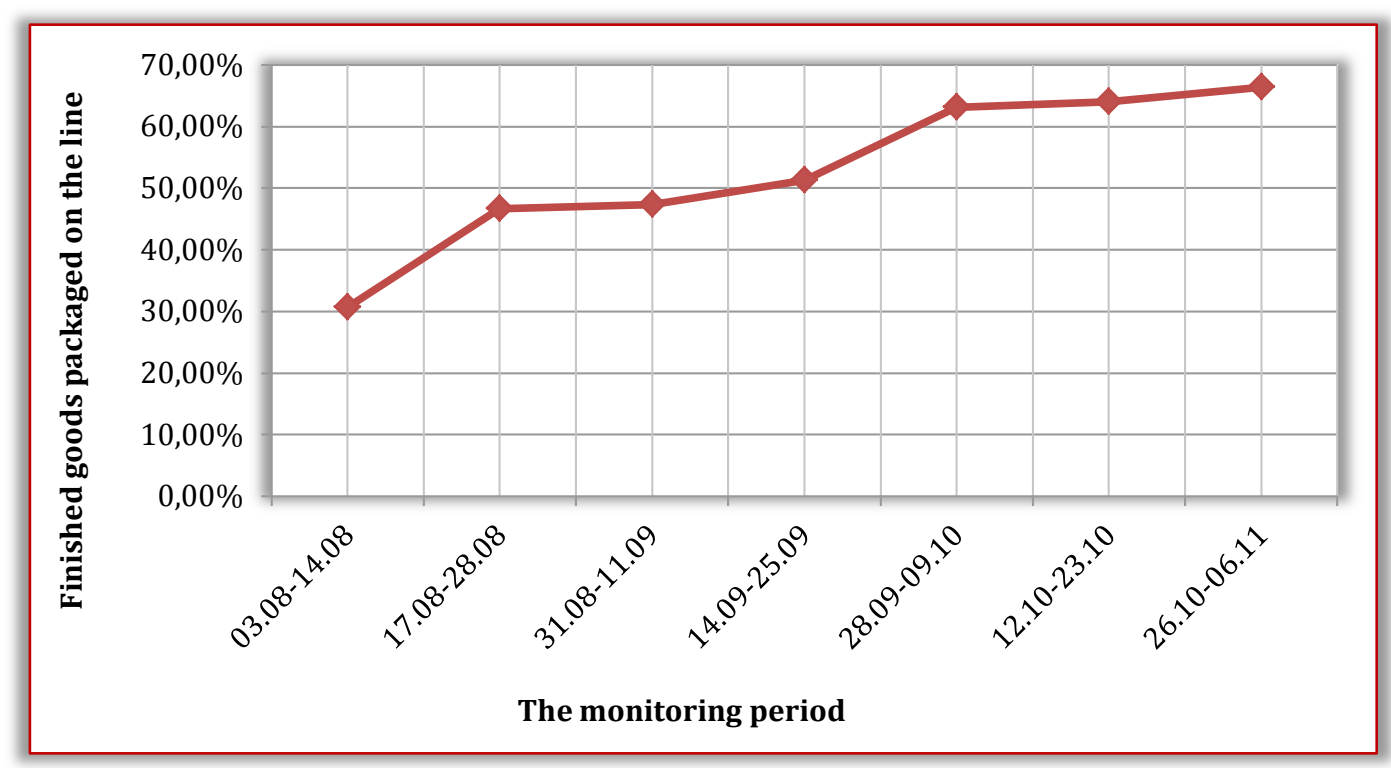

Figure 6. The monitoring graph

The factory complies with ISO / TS 16949, which is accredited by TUV SUD Romania. The purpose of this standard is to develop a quality management system to generate continuous improvement, emphasizing 
defect prevention activities, reducing variation and waste minimization in the supply chain of the auto industry.

Improving implemented and presented in this paper was implemented in the company. After the analysis in this paper on quality assurance in the logistics department of the factory, it ensures the production of sensors quality, preventing the defects, if any of these defects are ways to improve in order to avoid recurrence of such defects using quality tools (Poka Yoke analysis Failure Mode and Effects (FMEA) etc.). The 8D method application will result in improved products and processes is structured into eight disciplines, focusing on the synergy of the team. This is a popular method for problem solving because it is reasonably easy to teach and effective. Therefore, the Eight Disciplines of Problem Solving (8D) is a problem-solving tool used usually in response to the removal parameters or known product specifications set by customers and incorporates all the important aspects of problem solving: problem description, root cause analysis, correcting the problem and preventing the problem. The approach establishes a permanent corrective action based on statistical analysis of the problem and focuses on the origin of the problem by determining its root causes. Although it originally comprised eight stages, or disciplines, it was later augmented by an initial planning stage.

\section{REFERENCES}

[1] L. Moldovan, Managementul calităţii. Editura Universităţii „Petru Maior” din Târgu-Mureş, 2011

[2] L. Moldovan, Organizarea şi conducerea sistemelor calităţii. Editura Universităţii „Petru Maior” din Târgu-Mureş, 2011

[3] L. Moldovan, Metode de analiză şi evaluare a calităţii. Editura Universităţii „Petru Maior” din TârguMureş, 2011

[4] M. Olaru, A. Tanţău, Managementul producţiei şi al calităţii, Editura Economică Preuniversitaria, Bucureşti, 2002

[5] M. Olaru, Tehnici şi instrumente ale managementului calităţii, în Managementul calităţii şi protecţia consumatorului, Editura ASE, Bucureşti, 1997

[6] A. S. Stan, Logistica - suport curs

[7] www.boschrexroth.ro

[8] www.bosch.com 